following tubal ligation. $\mathrm{Lu}$ and $\mathrm{Chun}^{2}$ reported $50 \%$ of 1,055 cases, Williams $116.5 \%$ of 200 cases, and now Mr. Muldoon $24 \%$ of 374 cases. That such variations exist indicates inaccuracy, possibly owing to such factors as failure to define the dysfunctions, retrospective studies, and absence of comparable control groups. Until the true incidence of menstrual disorder in the nonsterilized community can be shown, I must consider the common subjective impression of poststerilization menorrhagia as unproved.

So far as other gynaecological disorders mentioned by $\mathrm{Mr}$. Muldoon are concerned, I doubt if anybody really considers prolapse, carcinoma of cervix, erosion, etc., to be caused by tubal ligation. I would of course agree with him that if these conditions are thought to exist prior to tubal ligation, then consideration ought to be given to selective hysterectomy rather than tubal ligation, but I am sure most of us have been doing this for a considerable time anyway.-I am, etc.,

B. Alderman

Women's Hospital,

Liverpool 8

1 Williams, E. L., Jones, H. E., and Merrill, R. E., American fournal of Obstetrics and Gynecology, 1951, 61, 423.

Gun 1967,74,875, of the British Commonwealth

Institutional Neurosis

SIR,-In his review of J. K. Wing's book (20 November, p. 496) Dr. H. R. Rollin states that the term "institutional neurosis" is a misnomer and draws comfort from Dr. Wing's assertion "Institutionalism is not a neurosis."

While not wishing to promote the use of a term ascribed to me (but I suspect widely used before I heard it), I feel I must defend its adoption by a recapitulating the reasons I prefer it. The term "institutional" does not imply that institutions are the only cause of the disorder, but that it was first generally recognized in institutions-as the use of Bornholm in Bornholm disease. The term neurosis is used rather than psychosis since the syndrome itself does not interfere with the patient's ability to distinguish between reality and phantasy-indeed, the passivity adjusts the individual to the demands of the institution but at the same time hamper adjustment to the world outside. ${ }^{1}$ I agree with Dr. Wing that it is a set of attitudes and habits which impair (not preclude) readaption to everyday social living-but this is a fair definition of neurosis, in which a faulty set of attitudes and habits develop in early childhood in relation to members of the family and persist into adult life.

What fascinates $m e$ is the number of people rediscovering this condition every year or so who believe their formulation to be original and proceed to name it. Mea culpa. I listed six names given to the condition since 1939 in $\mathrm{my}^{\text {book }}{ }^{1}$ but there are many more.

For the record, I warned the authorities repeatedly that there was ill-will, absenteeism, neglect, and lack of co-op ration detrimental to patient care which would result in the loss of "hard won gains." The evidence was not adeouately investigated and in a recent letter to the North-east Metropolitan Regional Hospital Board (6 September,
1971) the Secretary of State criticized the uthorities in question for their neglect.

I agree with Dr. Rollin that chronic chizophrenia is incurable and psychiatric hospitals essential. Until the art of running them is appreciated and implemented they are probably better closed, the public inconvenienced, and the taxpayer obliged to pay three or four times as much for a less effective service fragmented into units in general hospitals, day care centres, and hostels, run by an administrative miasma in which committees, quarrels, and professional self indulgence command more time than patients. - I am, etc.,

Rochester State Hospital,

Russell BartoN

1 Barton, R., Institutional Neurosis. Bristol, Wright and Sons, 1966.

\section{Diuretic Dependence}

SIR,-Abuse of purgatives is well recognized in patients with anorexia nervosa, but a similar situation may also develop with diuretics, as illustrated by the following case.

A 24-year-old girl presented with a twomonth history of swelling of the face and feet. She denied ill-health, but 18 months previously had begun to diet when her boy friend had commented that she was too fat She admitted to an increasing preoccupation with her weight, and had restricted her diet to an estimated 800 calaries daily. On this her weight had fallen from approximately $70 \mathrm{~kg}$ to $41 \mathrm{~kg}$ (height 175 $\mathrm{cm})$. Amenorrhoea had developed one year previously, and had been latterly treated with the contraceptive pill, which induced trivial withdrawal bleeding on one occasion only. With the onset of oedema, she received frusemide $40 \mathrm{mg}$ daily, which resulted in a good diuresis and further weight loss, but produced postural giddiness. Her social history revealed many problems in the psychosexual sphere.

On admission she was sallow and emaciated with lax skin and acrocyanosis. Her blood pressure was $80 / 60$, with a postural fall to 60 systolic, and her pulse was $42-48 / \mathrm{min}$. Though she complained of oedema none could be detected. Investigations showed a normal blood count, E.S.R., electrolytes, liver function tests, serum proteins, calcium, cholesterol, and protein bound iodine. The blood urea was $61 \mathrm{mg} /$ $100 \mathrm{ml}$ with a creatinine clearance of $38 \mathrm{ml} / \mathrm{min}$., rising to $75 \mathrm{ml} / \mathrm{min}$ on discharge. Both the urine and an I.V.P. were normal. Corticosteroid levels were raised: plasma cortisol 38 (midnight), $50.5 \mu \mathrm{g} / 100$ ml (9 a.m.); urinary 17-OH corticosteroids 13.1, 17-ketosteroids $16 \cdot 1 \mathrm{mg} / 24 \mathrm{hrs}$. The patient refused inpatient therapy and was discharged taking cyproheptidene as an appetite stimulant. However, shortly afterwards, her boy friend reported that despite our advice, she had continued to take frusemide for the alleged swelling of her face, and had tried unsuccessfully to obtain a further supply. On questioning she clearly showed a pronounced dependence for diuretics as a means to further weight loss. Subsequently this resolved, and she has slowly improved on outpatient therapy.

Oedema occurs commonly during the course of anorexia nervosa though its cause is often not clear. ${ }^{1}$ Treatment with diuretics, as in this case, may reduce the already diminished blood pressure and renal perfusion further, and may lead to a dependence similar to that with purgatives. Though not present in this case, electrolyte disturbance may be severe as in two previously recorded cases $^{2}$ of diuretic abuse. Increasing use of powerful diuretics makes this hazard more likely, and should obviously be avoided in the symptomatic treatment of oedema, particularly young women in whom anorexia nervosa may be present.-We are, etc.,

C. Davidson

TREVOR SILVERSTONE

Department of Psychological Medicine,

St. Bartholomew's Hospital,

London E.C.1

1 Crisp, A. H., World Review of Nutrition and

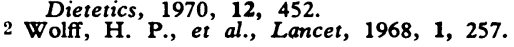

\section{Rights of Next of Kin}

SIR,-A university student, a former patient of mine who had consulted me during her vacation, was recently admitted to hospital by the university health service following an overdose. After her discharge from hospital she was admitted to the medical care centre of the university health service for a few days' observation. The university authorities did not inform the mother as next of kin either of her admission to hospital or of her admission to the university medical centre, apparently on the grounds that this would be a breach of confidence. The hospital likewise did not inform the next of kin.

While upholding the confidentiality of medical consultation as being one of the corner stones of our professional code of ethics I nevertheless feel that the rights and responsibilities of next of kin are equally important. In this particular case, the patient could have died without the mother having the opportunity to be with her. I would hope that this is not likely to become standard practice throughout the country and my reason in writing is to draw the attention of the profession to this relatively new development.-I am, etc.,

Birtley

H. A. F. MACKAY

Skin Reactions to Ampicillin

SIR,-Thank you for your leading article on "Skin Reactions to Ampicillin" (22 January, p. 195). E. T. Knudsen's statement ${ }^{1}$ that urticarial reactions are no commoner with ampicillin than with other penicillins is of particular importance. May I add further evidence from Dutch studies which may support his statement.

In these studies two brands of ampicillin have been compared (Penbritin and Amfipen). These trials suggest that ampicillin does give rise to a higher incidence of side effects (other than urticarial reactions) than penicillin. However, when we compare the frequency of erythematous reactions in patients treated with Penbritin with that in patients treated with Amfinen, we do find an incidence of $5.9 \%$ and $3.2 \%$ respectively. A tentative explanation by the manufacturer is that Amfinen is produced by a chemical process which gives a product free from protein particles, and therefore causes less side effects than other ampicillins produced by a biological process.

I am not sure how many different brands of ampicillin exist on the British market, 